DOI: $10.15290 /$ bsl.2018.13.17

\author{
Monika Sagało \\ Uniwersytet Jagielloński \\ Wydział Filologiczny \\ e-mail: monika.sagalo@doctoral.uj.edu.pl \\ ORCID: 0000-0002-6727-815X
}

\title{
Motyw urody kobiecej w utworze Obraz panej krásnej perem malovaný, která má v Trnave svoje prebýuání Štefana Ferdinanda Seleckiego
}

Miłość do kobiety i próba opisu jej urody stanowią jeden z podstawowych tematów w literaturze, pojawiający się od starożytności, który ulegał modyfikacjom w poszczególnych kulturach i epokach. Spojrzenie na miłość zmieniało się w zależności od warunków (politycznych, społecznych, religijnych), a stworzenie jego artystycznych reprezentacji stanowiło dla twórców nie lada wyzwanie. Dzieła poświęcone miłości do dzisiaj są przedmiotem badań i refleksji. W literaturze słowackiej najstarsze znane utwory miłosne powstały w średniowieczu (utwór o zabarwieniu erotycznym Ó milá panna, čo ty máš, czy łacińska poezja uprawiana przez studentów). Z okresu renesansu zachowało się dziewięć dzieł: jeden wierszowany utwór Píseň o dvúch uherských pánoch a tureckého cisáre dcére i osiem innych zapisanych w zbiorze Fanchaliho kódex (z lat 1603-1604) - są one przykładami liryki dworskiej z wyraźnymi wpływami romańskimi ${ }^{1}$. W fazie rozkwitu barokowej literatury utwory miłosne należały do najpopularniejszych gatunków. Rozwijał się w tym okresie nurt poezji oficjalnej (obok obiegu nieoficjalnego), ale kwitła również twórczość, która nie ukazywała się drukiem².

\footnotetext{
1 Zob. J. Minárik, Vysvetlivky, w: Amor diktoval, lásku spisoval. Výber zo slovenskej rukopisnej l’úbostnej poézie (1560-1860), edične pripravil J. Minárik, Bratislava 1979, s. 322-324.

2 Słowacja w okresie baroku była częścią państwa Habsburgów. Kontrreformacja stała się ogniwem łączącym dynastię panujących władców i Kościół katolicki przeciwko innowiercom
} 
Najwięcej zachowanych świeckich utworów lirycznych $\mathrm{z}$ epoki baroku pochodzi z końca XVII wieku i XVIII wieku, a wśród nich szczególnie wyróżnia się Obraz panej krásnej perem malovaný, která má v Trnave svoje prebývání Štefana Ferdinanda Seleckiego (ok. 1675-?) $)^{3}$ z 1701 roku. Jest to jedyny zachowany barokowy utwór z gatunku liryki miłosnej ze znamionami liryki dworskiej, wysławiający urodę tajemniczej mieszkanki Trnawy, który „napísal Selecký na počest' podporovatel'ky mladých básnikov Kataríny Carbortrany (?)" ${ }^{4}$. Obraz panej krasnej... na tle słowackiej świeckiej poezji barokowej wyróżnia się nie tylko cechami gatunkowymi: dzieło liczy 354 wersy, napisane jest rymowanym dwunastozgłoskowcem; inne utwory miłosne przybierają krótsze formy, są także podzielone na strofy ${ }^{5}$. O jego wyjątkowości przesądza jednak przede wszystkim przynależność do poezji dworskiego typu, w odróżnieniu od pozostałych utworów barokowych, które zostały przez Jozefa Minárika podzielone na kilka grup: pierwszą z nich stanowi poezja artystyczna uprawiana zgodnie $z$ duchem panującej mody - tzw. poezja modna (alamódová l'úbostná poézia), drugą tzw. poezja półludowa, zaś trzecią ludowa ${ }^{6}$. W utworze Obraz panej krasnej..., jak i w poezji modnej, pojawiają się wyraźne wpływy renesansowe. W literaturoznawstwie słowackim istnieje interpretacja, wedle której wizerunek Słowianki utrwalony przez Seleckiego, będący połączeniem urody i cnót, może być alegorycznym obrazem uniwersytetu, który powinien kształcić, uwrażliwiać ludzi na piękno i skłaniać do szlachetnego zachowania. Tak jak pani z Trnawy wywołuje w podmiocie lirycznym zachwyt nad wdziękiem i wiernością wyznawanym zasadom, tak uniwersytet jest miejscem, które wychowa pokolenia studentów ukształto-

i zwolennikom zmian w systemie państwowym. Zob. J. Mišianik, Pohl'ady do staršej slovenskej literatúry, Bratislava 1974, s. 170-171. W baroku literatura słowacka rozwijała się w dwóch obiegach: w nurcie oficjalnym drukowano utwory zgodne z wymogami cenzury, a w nieoficjalnym rozpowszechniane były utwory $\mathrm{w}$ formie rękopisów - należała do nich m.in. alamódová l'úbostná poézia [zob. S. Šmatlák, Dejiny slovenskej literatúry I (9.-18. storočie), Bratislava 1997, s. 245-246].

3 Zob. Slovník slovenských spisovatel'ov, pod vedením V. Mikulu, Praha 1999, s. 388. W tłumaczeniu J. Waczkowa tytuł utworu brzmi: Obraz pięknej pani, piórem malowany, która ma w Trnawie dom umiłowany [Obraz pięknej pani..., przeł. J. Waczków, w: Antologia poezji słowackiej, red. J. Waczków, Warszawa 1981].

4 „napisał Selecký na cześć protektorki młodych poetów, Kataríny Carbortrany (?)” [J. Minárik, Baroková literatúra. Svetová. Česká. Slovenská, Bratislava 1984, s. 178 - tłum. M.S.]. Trnawa w okresie powstawania utworu znajdowała się pod panowaniem dynastii Habsurgów w Królestwie Węgier [zob. W. Felczak, Historia Wegier, Wrocław 1983, s. 128-129 oraz B. Suchoń, Barok stowiański pod berłem Habsburgów, w: Studia porównawcze z literatur słowiańskich, red. R. Łużny i Z. Niedziela, Wrocław 1992, s. 54].

5 Zob. J. Mišianik, Pohl'ady do staršej slovenskej literatúry, Bratislava 1974, s. 212, 214.

6 Zob. J. Minárik, Vysvetlivky, w: Amor diktoval..., edične pripravil J. Minárik, Bratislava 1979, s. $327-333$. 
wane nie tylko intelektualnie, ale też pod względem moralnym. Jak widać, utwór Obraz panej krasnej... (albo jego fragment) można interpretować wieloznacznie $^{7}$, tutaj jednak ograniczę się do prezentacji jednej kwestii, zasygnalizowanej w tytule artykułu ${ }^{8}$. W pracy zajmę się tylko wybranymi fragmentami obszernego opisu urody słowackiej pani i zastanowię się nad tym, dlaczego autor postanawił wzbogacić swoje dzieło odwołaniami do postaci znanych w kulturze.

$\mathrm{Z}$ utworu Seleckiego wyłania się obraz jasnowłosej pani o nienagannych manierach, dbającej o reputację, delikatnej i czystej. Podmiot liryczny patrzy na nią z pewnym dystansem. $Z$ pewnością jej fizyczna uroda oddziałuje na mężczyzn, ponieważ przybywają $\mathrm{z}$ dalekich krain, aby móc ją podziwiać: „Kolko je kolovačky krajín v Europie, / všecky pro ňu vied'á juž včil o Trnavie" $^{\prime \prime}$ [„,Toż w całej Europie, w całym świecie prawie, / dzięki niej już wszyscy wiedzą o Trnawie"10], jej zachowanie zmusza ich jednak do powściągliwości, wyznaczając granice wzajemnych relacji. O zdystansowaniu podmiotu lirycznego wobec pięknej Słowianki pisze Milan Hamada:

Je pravda, že táto báseň, ktorej autorom je azda študent trnavskej univerzity, nedosahuje úroveň najpriebojnejších básní Fanchaliho kódexu. Viac ako spomínané básne je závislá od noriem dvorno-kurtoázneho básnenia. Zatial' čo v spomínaných básňach je zrejmá nadradenost' l'úbostného vzplanutia a l'úbostnej túžby nad cnost', v Seleckého básni sú úplne v duchu stredovekých noriem všetky citové, vôlové a rozumové kategórie podriadené cti. $S$ tým súvisí idealizovaný opis krásnej panej, zdôrazňovanie jej panenskosti a priamo vyslovená túžba l'úbostného vzt'ahu ako služby ${ }^{11}$.

7 Zob. Slovnik slovenských spisovatel'ov, s. 388.

8 Z kolei polski badacz Jacek Kolbuszewski w swoim artykule podważa tezę o alegorycznym odczytywaniu utworu [zob. J. Kolbuszewski, Obraz panej krásnej perem malovaný která má v Trnave svoje prebývání, w: tegoż, Na południe od Tatr. Studia o literaturze słowackiej, Wrocław, s. 35].

9 Š.F. Selecký, Obraz panej krásnej perem malovaný, která má v Trnave svoje prebývání, w: Amor diktoval..., edične pripravil J. Minárik, Bratislava 1979, s. 49.

10 Š.F. Selecký, Obraz pięknej pani..., s. 78. Korzystam z tłumaczenia autorstwa J. Waczkowa, kóry przełożył fragmenty słowackiego dzieła na język polski. W przypadku, gdy fragmenty cytowane $\mathrm{w}$ pracy nie są przetłumaczone na język polski, ich tłumaczenia pochodzą ode mnie.

11 „To prawda, że ten wiersz, którego autorem jest chyba student uniwersytetu w Trnawie, nie dorównuje poziomem najbardziej uznanym dziełom z Kodeksu Fanchaliego. Bardziej niż od wspomnianych wierszy zależny jest on od dworsko-kurtuazyjnego pisania wierszy. Podczas gdy we wspominanych wierszach jest oczywisty prymat miłosnej gorączki i miłosnej tęsknoty nad cnotą, w wierszu Seleckiego całkiem w duchu średniowiecznych norm wszystkie kategorie uczucia, woli i rozumu są podporządkowane czci. Z tym jest związany wyidealizowany obraz pięknej pani, podkreślanie jej dziewiczości i bezpośrednio wysłowiona tęsknota w relacji miłosnej jako służby" [M. Hamada, Zrod novodobej slovenskej kultúry, Bratislava 1995, s. 219-220 przeł. M.S.]. 
W utworze Seleckiego podmiot liryczny jest pełen szacunku wobec pani z Trnawy i zachwytu jej fizyczną urodą. Swoją postawą przypomina średniowiecznego rycerza, któremu głębokie uczucie do kobiety pozwoli osiągnąć doskonałość:

Przecież szlachetna służba kobiecie wyłoniła się z miłości zmysłowej, pozbawionej pretensji do zaspokojenia. Teraz oto miłość stała się polem, na którym rozkwitała wszelka doskonałość etyczna i estetyczna. Według teorii miłości dworskiej szlachetny kochanek staje się przez swą miłość cnotliwy i czysty ${ }^{12}$.

W dziele odnajdujemy klasyczny topos skromności - podmiot liryczny przyznaje, że nie jest pewien, czy posiada wystarczający kunszt literacki, aby w zadowalający sposób oddać piękno Słowianki „od hlavy až k patám” ${ }^{13}$. Posługuje się przy tym wieloma chwytami charakterystycznymi dla stylu barokowego, między innymi rozbudowanymi opisami, epitetami (,jjako bramor hladký"14 [,jak marmur najgładszy" $\left.{ }^{15}\right]$ ), odniesieniami do znanych postaci kobiecych rodem $\mathrm{z}$ antyku ${ }^{16} \mathrm{czy}$ porównaniami:

Oči rozkoš nevím, jak mám vychvalovat', / pre velikú krásu jakú jim chválu dat'. / Prirovnám jich k očám sokola drahého. / Hambu snad dostanem z podobenství toho, / leb jesli sokol má ve svých očách pieknost, / má tá šestkrát viečšú, kterej je táto cnost ${ }^{17}$.

[Oczu jasnych nie wiem, jak mam głosić chwałę, / by wysłowić blask ich, piękno niebywałe. / Do oczu sokolich porównam je oto, / ale to mnie pewnie okryje sromotą, / bo jeśli wspaniale błyszczy wzrok sokoła, / jej wzrok stokroć większy blask sieje dokoła... $]^{18}$

12 J. Huizinga, Jesień średniowiecza, przeł. T. Brzostowski, Warszawa 1996, s. 135.

13 Š.F. Selecký, Obraz panej krásnej..., s. 43. Dosłowny przekład brzmi: „od głowy aż do pięt”, co odpowiada polskiemu frazeologizmowi "od stóp do głów”.

14 Š.F. Selecký, Obraz panej krásnej..., s. 43.

15 Š.F. Selecký, Obraz pięknej pani..., s. 77.

16 Zob. J. Minárik, Baroková literatúra..., s. 179.

17 Š.F. Selecký, Obraz panej krásnej..., s. 44.

18 Š.F. Selecký, Obraz pięknej pani..., s. 77. Sokół w literaturze i kulturze symbolizuje między innymi bystrość i przenikliwość spojrzenia [zob. W. Kopaliński, Słownik symboli, Warszawa 2006, s. 397]. Porównanie do oczu sokoła pojawia się w sonecie 72. Petrarki, jednakże w innym kontekście: „Jakbądźby oczy z których w ciebie patrzę, / Aby w twej duszy skruszyć krnąbrną wolę, / Przyćmiły nieco blaski swe sokole, / To jeszcze - nad twarz Laury, czyż gdzie gładsze / Widziałeś lica? - Przyznaj to rzewliwie - / Twojemi łzami ja się chętnie żywię. -" [Pieśni Petrarki, przeł. Felicyan, Warszawa 1881, s. 136]. Występujące w utworze Seleckiego porównanie oczu ukochanej do oczu drapieżnego ptaka wydaje się zaskakujące, chociaż zamiarem autora była ich pochwała. Sokół w słowackiej poezji barokowej pojawia się także jako jeden z ludowych elementów w poezji modnej - 'sokolík' to jedno z określeń mężczyzny [zob. J. Minárik, Vysvetlivky, w: Amor diktoval.., edične pripravil J. Minárik, Bratislava 1979, s. 327]. 
Pierwszą osobą, którą przywołuje podmiot liryczny, chcąc opisać włosy mieszkanki Trnawy, jest biblijna Maria Magdalena. Była to postać często ukazywana w sztuce baroku jako archetyp pokutującej grzesznicy, dobrowolnie odrzucającej swoje dawne życie ${ }^{19}$, ale również jako przykład pięknej kobiety ${ }^{20}$ - w utworze Seleckiego Maria Magdalena pojawia się w takim właśnie kontekście. Podmiot liryczny nie ukazuje jej jako wzór pobożności, tylko kobietę o niezwykłej urodzie, dlatego przywołuje jej postać przy opisie włosów pani z Trnawy:

Začnem od vrch hlavy, kde rostú ty vlasy, / které sú od stíbra i od zlata drahší, / nad skofium vzácne i sú vyvýšené, / Marí Magdaléne k vlasám prirovnané. / Jak zlato táhnuté na slunci subtilne, / tak ležá na hlavie její rozdelené $-{ }^{21}$.

[Zacznę od czubka głowy, tam rosną te włosy, / które są od srebra i złota droższe, / i cenniejsze od rzeczy złotymi lub srebrnymi nićmi wyszywanymi, / do włosów Marii Magdaleny podobne. / Jak złoto muśnięte na słońcu subtelnie, / tak leżą na głowie jej rozdzielone -. - przeł. M. S.]

Włosy mieszkanki Trnawy są jasne, co charakterystyczne dla słowiańskiego typu urody. Ten ideał jest związany z tradycją petrarkistyczną - kobieta o takim kolorze włosów stała się ucieleśnieniem piękna ${ }^{22}$. Ze względu na odcień - porównywany do złota - włosy opisywanej kobiety są dla podmiotu lirycznego cenniejsze niż najdroższe kruszce i stanowią jej prawdziwą ozdobę. Skąd przy tej okazji pojawia się biblijna postać? W Nowym Testamencie nie znajdziemy wielu informacji o Marii Magdalenie. Długo była utożsamiana z jawnogrzesznicą, namaszczającą drogim olejkiem nogi Chrystusowi ${ }^{23}$. W Ewangelii według św. Łukasza czytamy o wydarzeniu z udziałem nieznanej z imienia żydowskiej kobiety:

A oto kobieta, która prowadziła w mieście życie grzeszne, dowiedziawszy się, że jest gościem $\mathrm{w}$ domu faryzeusza, przyniosła flakonik alabastrowy olejku, i stanąwszy z tyłu u nóg Jego, płacząc, zaczęła łzami oblewać Jego nogi i włosami swej głowy je wycierać. Potem całowała Jego stopy i namaszczała je olejkiem ${ }^{24}$.

19 Zob. E. Krawiecka, Jasna ciemnego świata pochodnia..., Poznań 1997, s. 39-40.

20 W książce A. Borowiec czytamy: „Nie zawsze przedstawienia świętej były zgodne z wymogami kultu, istniały bowiem jej wyobrażenia eksponujące głównie nagość, piękno kształtów kobiecego ciała" [A. Borowiec, Literatura i tajemnica..., Kraków 2007, s. 42].

21 Š.F. Selecký, Obraz panej krásnej..., s. 43.

22 Zob. Z. Kuchowicz, Miłość staropolska. Wzory - uczuciowosśc - obyczaje erotyczne XVI-XVIII wieku, Łódź 1982, s. 228.

23 P. Lisicki pisze: „Najpierw papież utożsamił jawnogrzesznicę z Marią z Betanii, potem tę drugą z Marią Magdaleną" [P. Lisicki, Tajemnica Marii Magdaleny, Kraków 2014, s. 107].

24 Łk 7, 37-38 Scena namaszczenia Chrystusa pojawia się także w dwóch innych Ewangeliach; więcej informacji na ten temat przywołuje P. Lisicki w swojej książce [P. Lisicki, Tajemnica Marii Magdaleny, Kraków 2014, s. 107-111]. 
Przypuszczalnie jej włosy były długie i piękne, dlatego zwróciły uwagę gości przebywających $\mathrm{w}$ domu faryzeusza. Tę biblijną scenę można zapewne traktować jako źródło, z którego czerpał autor słowackiego utworu, przywołując w swoim opisie postać Marii Magdaleny. W historii zapisanej w Ewangelii włosy kobiety posłużyły złożeniu hołdu Chrystusowi, zaś w słowackim utworze są one tylko chlubą i jednym z atutów urody Słowianki. Niemniej porównanie ich do włosów Marii Magdaleny sprawia, że autor już w pierwszych wersach opisu fizycznego słowackiej piękności w szczególny sposób podkreśla ten atrybut.

Drugą kobietą o rodowodzie biblijnym, do której odwołuje się podmiot liryczny, jest starotestamentowa Judyta, stawiająca czoło Holofernesowi, słynąca $\mathrm{z}$ odwagi oraz wielkiej urody, co znajduje potwierdzenie we fragmentach Księgi Judyty: „A Judyta weszła i zajęła swoje miejsce. I zachwycił się Holofernes w sercu swoim jej widokiem i dusza w nim doznała gwałtownego wzruszenia" ${ }^{25}$. Podobnie jak Maria Magdalena, tak i postać Judyty była popularnym toposem, szczególnie $\mathrm{w}$ XVII wieku ${ }^{26}$. Wspomina o niej także podmiot liryczny w utworze Obraz panej krásnej..., sławiąc fizyczne piękno mieszkanki Trnawy:

Tá by lud krest'anský z rukú neprítela / skrz svú mocnost velkú pieknosti vytrhla. / Od tej by zahynút mosel Holofernes, / ked by Trnavu chtel dostat zajtra neb dnes. / To je druhá Judit, krású ozdobená; / to je, kterej v sviete rovná není žádná ${ }^{27}$.

[Ta by lud chrześcijański z rąk nieprzyjaciela / poprzez moc swojego piękna wyciągnęła. / Od niej mógłby zginąć Holofernes, / gdyby chciał Trnawę zdobyć jutro albo dziś. / To jest druga Judyta, pięknem ozdobiona; / taka, której na świecie żadna nie dorówna. - przeł. M. S.]

W utworze pojawia się odniesienie do konkretnej sceny, w której Holofernes zakochuje się w żydowskiej kobiecie. Podmiot liryczny osadza ten biblijny motyw w otaczających go realiach Trnawy i zaznacza, że gdyby starotestamentowa historia miała się rozegrać na europejskiej ziemi, a miasto byłoby oblegane przez nowego Holofernesa, rolę biblijnej Judyty odegrałaby piękna Słowianka, ponieważ podobnie jak jej pierwowzór, swoim wdziękiem pozyskałaby względy najgorszego wroga. Podmiot liryczny koncentruje się

\footnotetext{
25 Jdt $12,16$.

26 ,Już w pierwszej połowie XVI wieku Judyta stała się ulubioną bohaterką dramatopisarzy i artystów plastyków obszaru niemieckojęzycznego. Najwięcej dzieł zainspirowanych Księgą powstało do schyłku XVII wieku" [A. M. Misiak, Judyta - postać bez granic, Gdańsk 2004, s. 7].

27 Š.F. Selecký, Obraz panej krásnej..., s. 50.
} 
na potędze urody pani z Trnawy, nie wspominając o odwadze, a przecież dla Judyty fizyczne piękno stanowiło przede wszystkim środek służący wyzwoleniu miasta. Żydowska kobieta musiała się wykazać również sprytem i przekonaniem o słuszności własnego postępowania, aby wkraść się w łaski asyryjskiego wodza, a potem zabić go i powrócić do rodaków ${ }^{28}$. Nie dowiadujemy się jednak, czy słowacka pani dorównywała śmiałością biblijnej postaci. W słowackim utworze podmiot liryczny dostrzega tylko jeden przymiot Judyty - jej oszałamiający fizyczny wdzięk - i w tym kontekście przywołuje jej postać. Porównaniem mieszkanki Trnawy do starotestamentowej bohaterki podkreśla jej słowiańską urodę, którą mogłaby wykorzystać w przypadku niebezpieczeństwa.

W utworze Obraz panej krásnej... występują także odwołania do innych postaci kobiecych, znanych z mitologii, wśród których pojawia się rzymska bogini Diana:

Prsú cnost má viečší, než mnela Diana, / lebo jest nad inší všecky vyvýšená. / Vyše osmi rokú jak paňú zostala, / poškvrny panenství žádnej nepoznala. / Žádné ješče dieta prsú nematalo, / nikedy matky menem ješče nenazvalo. / Neví, čo je bolest porodu t'ažkého, / je pod menem panej hodná panenského. / Nič by pro čistotu tu čudné nebylo, / ked by z prsú její lilium vykvitlo ${ }^{29}$.

[Piersi są jej większą zaletą niż Diany, / bo nad wszystkie inne jest zawsze wywyższona. / Ponad osiem lat temu panią została / skazy na dziewictwie żadnej nie doznała. / Żadne dziecię jeszcze piersi nie dotykało, / nigdy matką jeszcze żadne nie nazwało. / Nie wie, co to bóle porodu ciężkiego, / jest pod mianem pani stanu dziewiczego. / Nie będzie dla czystości to rzecz wzniosła, / gdyby z jej piersi lilia wyrosła. - przeł. M. S.]

W przeciwieństwie do miłosnych utworów staropolskich, podmiot liryczny unika szczegółowego opisu kobiecego biustu ${ }^{30}$. Komplementuje tę część ciała, ale odnosi się do niej z dużą dozą szacunku, uciekajac od dosłownych, eksponujacych fizyczność opisów. Odwołuje się przy tym do bogini Diany, uchodzącej między innymi za kobietę niedostępną: „nie pomyślała jednak o małżeństwie i została na zawsze dziewicą, jak Atena. Dawano jej przydomek Czystej i wiedziano powszechnie, że nie pozwala nawet spojrzeć

\footnotetext{
${ }^{28}$ Judyta zabija Holofernesa z modlitwą na ustach: „I podeszła do słupa nad łożem przy głowie Holofernesa, zdjęła jego miecz ze słupa, a zbliżywszy się do łoża ujęła go za włosy i rzekła: »Daj mi siłę w tym dniu, Panie, Boże Izraela!« I uderzyła go dwukrotnie z całej siły w kark, i odcięła głowę" [Jdt 13, 6-8].

29 Š.F. Selecký, Obraz panej krásnej..., s. 45.

30 Zob. Z. Kuchowicz, Miłość staropolska, s. 235.
} 
na siebie mężczyznom..." ${ }^{31}$. W ten sposób podmiot liryczny podkreśla dziewictwo słowiańskiej piękności. Ponadto w utworze występuje symboliczne odniesienie do lilii, kwiatu stanowiącego symbol niewinności. Odwoływanie się zarówno do mitologicznej bogini, jak i lilii pokazuje, że podmiot liryczny w swojej skromności zachwyca się przede wszystkim czystością pani z Trnawy.

Inną postacią o mitologicznym rodowodzie jest grecka muza tańca Terpsychora, jedna z dziewięciu muz Apollina, ze swoim nieodłącznym atrybutem - kitarą (lirą) ${ }^{32}$ : „Prsty tak subtilné jako Terpsichore, / které vzácné byli, hrajíc na cithare" 33 [„Palce ma subtelne jak te Terpsychory, / drogocenne były, dotykając kitary" - przeł. M. S.]. Delikatność palców mieszkanki Trnawy została zestawiona z dłońmi greckiej muzy, które musiały być zręczne i subtelne, aby mogła perfekcyjnie grać na lirze. Słowacką piękność charakteryzuje również gracja, z jaką się porusza, w czym podmiot liryczny również dostrzega podobieństwo do mitologicznej postaci:

Známá je z devátí Terpsichore jedna, / bohyna všem jinším v tanci predložená, / kterej tanečný krok tak byl ludom milý, / že s ním zarmúcení žalost odháňali. / Táto ne devátí, ale všeckým jedna / v tanci a svém kroku v cnostném predložená ${ }^{34}$.

[Terpsychora jedna z dziewięciu Muz grona / bogini nad inne w tańcu wyniesiona, / bo ludziom tak miłe było jej stąpanie, / że swych trosk zbywali, nie zważali na nie. / Nie z dziewięciu, lecz ze wszystkich jedna ona / nad inne w stąpaniu wdzięcznym wyniesiona! ${ }^{35}$ ]

Podmiot liryczny nie tylko zestawia piękną mieszkankę Trnawy z grecką muzą, ale stwierdza, że swoim wdziękiem $\mathrm{w}$ tańcu przewyższa ją gracją jest to wielki komplement, ponieważ Terpsychora uchodziła w tej dziedzinie za niedościgły wzór.

Kolejną postacią z mitologii rzymskiej, do której odwołuje się w utworze podmiot liryczny, jest Sybilla: „Život tak čistotnej chvály jest zaslúžil, / kterú sem o prsúch její cnostných mluvil; je pak na ten spúsob, jak mnela Sibylla, / dokad v velkej kráse v mladých letách byla” ${ }^{36}$ [„Na żywot pełen wielkiej chwały ten zasłużył, / gdym o cnotach jej piersi mówił; jest więc

\footnotetext{
31 J. Parandowski, Mitologia. Wierzenia i podania Greków i Rzymian, Poznań 1989, s. 55.

32 Jak pisze J. Parandowski, Terpsychora oznacza "Kochająca taniec” [J. Parandowski, Mitologia. Wierzenia i podania Greków i Rzymian, Poznań 1989, s. 53].

33 Š.F. Selecký, Obraz panej krásnej..., s. 45.

34 Tamże, s. 46.

35 Š.F. Selecký, Obraz pięknej pani.., s. 77.

36 Š.F. Selecký, Obraz panej krásnej..., s. 45.
} 
w tym względzie jak Sybilla, / która wielką pięknością w młodych latach była" - przeł. M. S.].

Sybilla była grecką wieszczką, która sprzedała rzymskiemu władcy Tarkwiniuszowi księgi z przepowiedniami, zwane Księgami Sybillińskimi ${ }^{37}$. Podmiot liryczny w utworze Seleckiego odwołuje się prawdopodobnie do postaci tzw. Sybilli Kumańskiej, kapłanki ze świątyni Apolla, która otrzymała od boga dar długowieczności, niestety bez gwarancji nieprzemijającej urody $^{38}$ - w utworze Seleckiego mieszkanka Trnawy jest porównywana do antycznej wróżbitki wyłącznie ze względu na jej piękno, nie zaś jego nietrwałość.

Podmiot liryczny wspomina także o kobiecie owianej legendą - rzymskiej Lukrecji, wiernej mężatce, która popełniła samobójstwo po tym, gdy została zgwałcona przez syna rzymskiego władcy ${ }^{39}$. Na jej wrażliwość i delikatność zwracano uwagę już w renesansowej liryce słowackiej - anonimowy autor w utworze Pane bože milý, tobet' se žaluji przywołuje Lukrecję jako przykład wierności: „Ano Lucretia, / Venus ušlechtilá / v milosti jest stálá, / verná Antifora, / tak ty ke mne stálá bud', / z serdce svého mne nespust', / deučičko má milá" ${ }^{0}$ [„,Tak Lukrecja, / Wenus szlachetna / w miłości jest stała, / wierna Antygona, / tak ty wobec mnie stała bądź, / z serca swego mnie nie wyrzuć, / dziewczyno ma miła" - przeł. M. S.].

Z kolei w utworze Seleckiego postać Lukrecji zostaje przywołana, gdy opis pani z Trnawy sprawia autorowi trudność:

O lúne denklavém nič neb málo mluvím, / jenž stydlivú stránkú tela tu byt vidím. / Položení jeho známé nemožu mnet, / čistotu vonící proto smím potvrdit, / též ho smím prirovnat k Lukrécii lúnu, / kterého čistoty cítil ten sviet vúnú ${ }^{41}$.

[O wątłym łonie nic lub mało powiem, / bo wstydliwą stronę ciała tu dostrzegam. / O jego położeniu nie mogę znać wiele, / jego czystość dlatego mogę potwierdzić, / śmiem je porównać do Lukrecji łona, / którego czystą woń czuł świat. - przeł. M. S.]

Podmiot liryczny, przez wzgląd na przyzwoitość i skromność, nie chce opisywać najintymniejszej z kobiecych części ciała; ucieka się więc do po-

\footnotetext{
37 Zob. J. Parandowski,Mitologia. Wierzenia i podania Greków i Rzymian, Poznań 1989, s. 228-229.

38 Zob. J. Westwood, Tajemnice miejsc niezwykłych, przeł. R. Gołędowski, Warszawa 1994, s. $48-50$.

39 Zob. J. Minárik, Vysvetlivky, w: Amor diktoval..., s. 346.

40 Pane bože milý, tobet' se žaluji, w: Amor diktoval..., s. 24.

41 Š.F. Selecký, Obraz panej krásnej..., s. 45.
} 
rówania słowackiej pani z Lukrecją, chcąc po raz kolejny podkreślić jej niewinność. Niewątpliwie czystość jest jednym z tych przymiotów, które ceni najbardziej u pani z Trnawy: ma na myśli nie tylko jej powściągliwość w relacjach damsko-męskich, ale także skromność i delikatność w codziennym zachowaniu. Jest to cecha wielokrotnie podkreślana $\mathrm{w}$ analizowanym opisie. O Lukrecji podmiot liryczny wspomina jeszcze raz, pod sam koniec, podsumowując obraz pani, jaki wyłania się z utworu: „To je príklad mravú, čistoty i kráse, / jako Lukrécia panna byt sviedči se" ${ }^{42}$ [„uosabia czystość, obyczajność zacną, / do panny Lukrecji przyrównać ją łacno" 43]. W tym fragmencie także podkreśla jej niewinność $\mathrm{w}$ połączeniu $\mathrm{z}$ urodą, jest to zatem, w jego przekonaniu, jedna z największych zalet mieszkanki Trnawy.

W utworze Obraz panej krasnej... pojawia się również odwołanie do Heleny Trojańskiej, tak opisanej przez Afrodytę: „W dalekiej Sparcie, w domu króla Menelaosa, żyje najcudniejsza kobieta na świecie, Helena" ${ }^{44}$. Podmiot liryczny mianem spartańskiej królowej określa mieszkankę Trnawy: „To je tá Helena, všem známá královná, / která ten čas v sviete sama byla krásná; / tá se svojú krású viečší svieta částku / obrátila k sobie, majíc u všech lásku" 45 [„To jest ta Helena, królowa wszem znana, / która wtedy w świecie piękna była sama; / ta swoim pięknem część świata większą / zjednała sobie, miłowaną będąc" - przeł. M. S.].

Fenomen Heleny polegał nie tylko na tym, że rozkochała w sobie trojańskiego królewicza, będąc żoną innego, co wywołało wieloletnią wojnę, ale także na tym, że po jej zakończeniu zdołała odzyskać miłość swojego męża ${ }^{46}$. Tym samym stanowi przykład kobiety o zniewalającej urodzie, która swoim wdziękiem i fizycznym pięknem potrafi kruszyć ludzkie serca i wzbudzać powszechną sympatię. Mieszkanka Trnawy jest nie tylko kobietą o niezrównanej aparycji, ale posiada także dar zjednywania sobie przyjaźni i miłości. Swoim zewnętrznym i wewnętrznym pięknem przyciąga innych, przy czym podmiot liryczny, akcentując fakt, że kieruje nią miłość, przemilcza obecny w greckim pierwowzorze motyw zbrojnego konfliktu, do którego przyczyniła się Helena. Słowacka piękność nie prowokuje sporów: jej powab przyciąga uwagę adoratorów, ale nie wzbudza w nich nienawiści i żądzy walki.

Podmiot liryczny odwołuje się również do antycznej postaci męskiej biblijnego Absaloma:

\footnotetext{
42 Tamże, s. 51.

43 Š.F. Selecký, Obraz pięknej pani.., s. 79.

44 J. Parandowski, Mitologia. Wierzenia i podania Greków i Rzymian, Poznań 1989, s. 176.

45 Š.F. Selecký, Obraz panej krásnej..., s. 51.

46 Zob. J. Parandowski, Mitologia. Wierzenia i podania Greków i Rzymian, Poznań 1989, s. 184.
} 
A od toho času, v který sem ju videl, / vierit víc nebudem - též sem v ten čas nechtel, / že by král Absolon ze všech najpieknejší / byl od pani tejto v nečem spúsobnejší; / vierím, že byl krásný, neb sem v knihách čítal, / o ní však istejší, jenž sem samú vídal - / ked by v ten čas žila, ked i Absolon žil, / nazdávám sa, že by pár sobie rovný bol. [...] Ona sama vierne, a ne inší žádná, / ke Absolonovi se prirovnat žádá ${ }^{47}$.

[A od tego czasu, gdy ją widziałem, / nie będę dłużej wierzyć - wtedy też nie chciałem, / że król Absalom ze wszystkich najpiękniejszy/ był od tej pani w czymś grzeczniejszy; / wierzę, że był piękny, bo w księgach czytałem, / jej jestem pewniejszy, bo sam ją widziałem - / gdyby ona w czasach Absaloma żyła, / mniemam, że to by para równa sobie była. [...] Ona sama wiernie, a nie inna żadna, / do Absaloma przyrównać się może. - przeł. M. S.]

W tym fragmencie zostaje ukazana postać Absaloma jako mężczyzny słynącego z wielkiej urody - podmiot liryczny skupia się tylko na jego fizycznym pięknie. Nawiązując do wyglądu biblijnego bohatera, pragnie wywyższyć i kolejny raz podkreślić wyjątkowość pani z Trnawy: jest ona tak niebywale piękna, że wraz z Absalomem mogłaby tworzyć idealną parę. W utworze Seleckiego brakuje odniesień do innych aspektów z życia syna króla Dawida; podmiot liryczny koncentruje się tylko na jego wyglądzie, podobnie jak w przypadku odwołań do biblijnej Judyty czy Marii Magdaleny ${ }^{48}$.

Nieprzypadkowo podmiot liryczny wymienia Helenę - obok Lukrecji - pod koniec swojego opisu. Porównanie z nimi stanowi rodzaj podsumowania katalogu zalet pani z Trnawy. W barokowym utworze Seleckiego pobrzmiewają wpływy renesansowej i petrarkistycznej poezji (ujawnia je model urody kobiecej: blond włosy, wysokie czoło, gładka cera, bystre oczy, zęby niczym perełki, biała szyja ${ }^{49}$ ), a podmiot liryczny po kolei wymienia i opisuje przymioty pani z Trnawy. W tekście odnajdujemy również echa średniowiecznych konwencji - podmiot liryczny stara się zachować dystans wobec kobiety, którą darzy tyleż uwielbieniem, co szacunkiem. Ponadto w utworze dostrzegamy liczne odniesienia do postaci znanych z historii i kultury, co pojawia się także w literaturze staropolskiej: „Poeci barokowi czerpali inspiracje

\footnotetext{
47 Š.F. Selecký, Obraz panej krásnej..., s. 48.

48 W Drugiej Księdze Samuela czytamy: „w całym Izraelu nie było człowieka tak pięknego jak Absalom. O nim wygłaszano pochwały: »Od stóp do głowy nie było na nim skazy. Kiedy strzygł swoją głowę - a strzygł ją zwykle co roku, bo było mu zbyt ciężko i musiał się strzyc włosy jego głowy ważyły dwieście syklów według królewskiej wagi«" [2 Sm 14, 25-26].

49 Zob. Š.F. Selecký, Obraz panej krásnej..., s. 43-45. W jednym z sonetów Petrarki odnajdujemy wzorzec urody: „Twarz - śnieg gorący, włosy - czyste złoto, / Rzęsy jak heban, oczy zaś - dwie gwiazdy, / Skąd miłość wszystkich celnie rani oto. / Perły - zęby, a róże purpurowe - / Wargi, w których brzmiał bólem wyraz każdy; / Westchnienie - płomień, łzy - kryształ u powiek" [F. Petrarka, Quel sempre acerbo..., w: Sonety do Laury, przeł. J. Kurek, Warszawa 2001, s. 40].
} 
z różnych źródeł: antycznych, biblijnych, średniowiecznych, renesansowych i z własnej współczesności, z zasobów obcych i rodzimych" ${ }^{50}$.

Selecký, tworząc portret pani z Trnawy, sięga po postacie kobiece ze starożytności, odwołując się przy każdej z nich do jednej, wybranej cechy, która ją charakteryzuje. Opisana arystokratka z Trnawy łączy w sobie te pojedyncze przymioty, które składają się w niej w idealną całość, wyróżniającą ją na tle kobiet z okolicznych krajów. Niezwykłe fizyczne piękno, jakim emanuje słowacka pani, koresponduje z pięknym wnętrzem, które wpływa na ludzi wokół. Jej uroda, opisana szczegółowo przez podmiot liryczny, staje się wzorem dla innych kobiet, ale słowiańska piękność ceniona jest nie tylko za walory fizyczne, lecz przede wszystkim za skromność i czystość. Zasługuje tym samym na ponadnarodową sławę, do czego przyczynia się autor, utrwalając jej wizerunek na kartach swego poematu.

\section{Bibliografia}

Borowiec Aleksandra (2007), Literatura i tajemnica. Studium o literaturze chorwackiej wieków dawnych, Kraków: Wydawnictwo Lexis.

Felczak Wacław (1983), Historia Węgier, Wrocław - Warszawa - Kraków - Gdańsk Łódź: Zakład Narodowy im. Ossolińskich.

Hamada Milan (1995), Zrod novodobej slovenskej kultúry, Bratislava: VEDA, vydavatel'stvo Slovenskej akadémie vied.

Huizinga Johan (1996), Jesień średniowiecza, przeł. T. Brzostowski, Warszawa: Państwowy Instytut Wydawniczy.

Kolbuszewski Jacek (2003), Obraz panej krásnej perem malovaný která má v Trnave svoje prebývání, w: J. Kolbuszewski, Na potudnie od Tatr. Studia o literaturze słowackiej, Wrocław: SUDETY, s. 29-42.

Kopaliński Władysław (2006), Słownik symboli, Warszawa: Oficyna Wydawnicza RYTM.

Kotarska Jadwiga (1980), Erotyk staropolski. Inspiracje i odmiany, Wrocław: Zakład Narodowy im. Ossolińskich - Wydawnictwo PAN.

Krawiecka Ewa (1997), Jasna ciemnego świata pochodnia. Z dziejów kultu św. Marii Magdaleny, Poznań: Kapituła Kolegiacka.

Kuchowicz Zbigniew (1982), Miłość staropolska. Wzory - uczuciowość - obyczaje erotyczne XVI-XVIII wieku, Łódź: Wydawnictwo Łódzkie.

Lisicki Paweł (2014), Tajemnica Marii Magdaleny, Kraków: Wydawnictwo M.

Mikulu Valeru [red.] (1999), Slovnik slovenských spisovatel'ov, Praha: Libri.

Minárik Jozef (1984), Baroková literatúra. Svetová. Česká. Slovenská, Bratislava: Slovenské pedagogické nakladatel'stvo. 50 J. Kotarska, Erotyk staropolski. Inspiracje i odmiany, Wrocław - Warszawa - Kraków - Gdańsk
1980, s. 70-71. 
Minárik Jozef (1979), Vysvetlivky, w: Amor diktoval, lásku spisoval. Výber zo slovenskej rukopisnej l'úbostnej poézie (1560-1860), edične pripravil Jozef Minárik, Bratislava: Tatran.

Misiak Anna Maja (2004), Judyta - postać bez granic, Gdańsk: Słowo/Obraz Terytoria. Mišianik Ján (1974), Pohl'ady do staršej slovenskej literatúry, Bratislava: VEDA, vydavatel'stvo Slovenskej akadémie vied.

Parandowski Jan (1989), Mitologia. Wierzenia i podania Greków i Rzymian, Poznań: Wydawnictwo Poznańskie.

Petrarka Francesco (2001), Quel sempre acerbo..., w: F. Petrarka, Sonety do Laury, przeł. J. Kurek, Warszawa: Prószyński i S-ka.

Petrarka Francesco (1881), Pieśni Petrarki, przeł. Felicyan, Warszawa [nakładem tłumacza].

Selecký Štefan Ferdinand, Obraz panej krásnej perem malovaný, která má v Trnave svoje prebývání, w: Amor diktoval, lásku spisoval. Výber zo slovenskej rukopisnej l'úbostnej poézie (1560-1860), edične pripravil Jozef Minárik, Bratislava: Tatran 1979.

Selecký Štefan Ferdinand (1981), Obraz pięknej pani, piórem malowany, która ma w Trnawie dom umiłowany (fragmenty), przeł. J. Waczków, w: Antologia poezji słowackiej, red. J. Waczków, Warszawa: Ludowa Spółdzielnia Wydawnicza.

Šmatlák Stanislav (1997), Dejiny slovenskej literatúry I (9.-18. storočie), Bratislava: Národné literárne centum.

Suchoń Barbara (1992), Barok słowiański pod berłem Habsburgów, w: Studia porównawcze z literatur słowiańskich, red. R. Łużny i Z. Niedziela, Wrocław - Warszawa Kraków: Zakład Narodowy im. Ossolińskich.

Westwood Jennifer (1994), Tajemnice miejsc niezwyktych, przeł. R. Gołędowski, Warszawa: Penta.

Žemberová Viera [red.] (1998) Rukovät' literatúry, Bratislava: Slovenské pedagogické nakladatel'stvo.

\title{
The Motif of Feminine Beauty in the Work Obraz panej krásnej perem malovaný, která má v Trnave svoje prebývání by Štefan Ferdinand Selecki
}

\begin{abstract}
The article discusses the description of feminine beauty in the Slovak baroque love poem Obraz panej krásnej perem malovaný, která má v Trnave svoje prebývání by Štefan Ferdinand Selecki. The author points to the essential function of feminine figures from the Age of Antiquity (Mary Magdalene, Judith, Diana, Terpsichore, Sibyl, Lucretia, and Helen). The poet invokes them to construct the main female character. The analysis considers the selection of figures and their features, which collaborate ideally to portray the "lady of Trnava". The stunning physical beauty of the Slovak aristocrat corresponds with inner grace, virtue and purity.
\end{abstract}

Keywords: baroque, Slovak literature, love poetry, poetic description 